\title{
DEVELOPMENT OF PASSENGER TRANSPORTATION BY RAILROAD FROM LITHUANIA TO EUROPEAN STATES
}

\author{
Jonas Butkevičius \\ Dept of Transport Management, Vilnius Gediminas Technical University, \\ Plytines g. 27, LT-10105 Vilnius, Lithuania. E-mail: vladas@ti.vgtu.lt
}

Received 15 December 2006; accepted 1 February 2007

\begin{abstract}
With the entry of Lithuania into the European Union, proper conditions for both Lithuanian and the EU inhabitants to comfortably travel by trains should be created. Lithuania should resume the direct communication by railroads with Poland. For that the passenger train route "Vilnius-Warsaw" should be opened; it would enable the national inhabitants to reach European countries by train and also the inhabitants of those countries to come by train to Lithuania.

The article gives an analysis of perspective passenger flows on the route "Vilnius-Warsaw", presents results of the study on passenger transportation of competitive sphere on this route, investigates technical-economical aspects of the train's launch, analyses the marketing strategy, gives a survey of links of this train's launch with the "Rail Baltica" project, provides with a presentation of the SWOT analysis. The author proposes to include St. Petersburg into the "Rail Baltica" route - this would increase flows of both - passengers and cargoes.

The article covers redistribution of the international passenger transportation market among different types of transport following the introduction of the "Rail Baltica" route.
\end{abstract}

Keywords: railroad, train, passenger transportation, passenger flows, passage, carriages, route, research, funds.

\section{Introduction}

Transport policy of the Government of the Republic of Lithuania has been oriented towards integration of the Lithuanian transport system into the European transport network and the transport services market. With Lithuania's entry into the European Union (EU), it is relevant to create conditions not only for Lithuanian, but also for other EU states' inhabitants to comfortably travel by train, as required by the EU directives [1-4].

The company "Lietuvos geležinkeliai" (LG) and Railroads of the Republic of Poland (further referred to as PKP), according to the agreement, signed on 31 July, 2000 , agreed to organize a direct route of passenger trains to Warsaw through Šeštokai, using the automatic wheel-gauge changing system in Mockava, the construction of which in 1999 was financed by the company "Lietuvos geležinkeliai". This agreement authorized both sides to form one Polish and one Lithuanian trains, which would run every day. As of 29 October 2000, the direct PKP passenger train traffic through this equipment on the route Warsaw-Šeštokai-Vilnius was opened. Due to a lack of funds, Lithuanian railroad train was not formed.

Launch of this train was approved by the Baltic Assembly, which in its resolution, as of 14 December 2002, "On Renewal of Traffic along I Kreta Corridor (Via Baltica magistral)", stimulated the Baltic cabinet council to make a decision on renewal of passenger railroad traffic along I Kreta corridor (Tallinn-RigaVilnius-Warsaw) and provide funds for investments into railroad equipment under the Baltic states' budgets, so that wheel-gauge of replaceable width, which could be used in the $1435 \mathrm{~mm}$ and $1520 \mathrm{~mm}$ width track railroads, would be equipped in carriages, also funds for yearly subsidies to cover maintenance costs, until the routes become profitable.

Lithuania makes transportation by railroads into the EU and other countries through Poland.

During the meeting, held on April 12, 2006, in Vilnius, Lithuanian and Polish Communication ministers exchanged the information on possibilities to relaunch a passenger train between Warsaw and Vilnius and agreed to contribute to organization of direct traffic, taking into account the available financing possibilities.

A significance of Vilnius-Warsaw route is undeniable, as it ensures maintenance of two-sided economical and cultural relations, also local inhabitants' trips through Warsaw into other EU countries.

\section{Flows of passengers, transported by railroads into European countries through Poland}

Dynamics of a number of passengers, transported by railroads from Lithuania into other countries in the 2002-2005 period, is presented in the Table. 
Dynamics of the number of passengers, transported by railroad from Lithuania to other countries during the 2002-2005 period, on MPT and OST-WEST tariffs (tickets sold in Lithuania)

\begin{tabular}{|l|c|c|c|c|c|}
\hline \multicolumn{2}{|c|}{ State } & \multirow{2}{*}{2002} & 2003 & 2004 & 2005 \\
\cline { 1 - 2 } nome & notation & & & & \\
\hline Germany & PKP & 8656 & 8577 & 8236 & 4290 \\
\cline { 1 - 2 } Czech Republic & DB & 1395 & 411 & 223 & 99 \\
\hline Austria & OBB & 224 & 152 & 140 & 59 \\
\hline Hungary & MAV & 53 & 57 & 49 & 4 \\
\hline Slovakia & ZSSK & 65 & 45 & 62 & 15 \\
\hline Holland & NS & 12 & 6 & 1 & 1 \\
\hline Croatia & HZ & 8 & 0 & 0 & 21 \\
\hline Switzerland & SBB & 0 & 0 & 0 & 0 \\
\hline Italy & FS & 78 & 16 & 15 & 2 \\
\hline Slovenia & SŽ & 31 & 13 & 0 & 1 \\
\hline Romania & ČFR & 3 & 0 & 3 & 0 \\
\hline Luxemburg & CFL & 4 & 0 & 0 & 0 \\
\hline $\begin{array}{l}\text { Serbia and Mon- } \\
\text { tenegro }\end{array}$ & JŽ & 3 & 10 & 1 & 2 \\
\hline France & SNCF & 5 & 0 & 5 & 0 \\
\hline Bulgaria & BDŽ & 1 & 2 & 0 & 0 \\
\hline Latvia & LDZ & 0 & 2 & 0 & 0 \\
\hline Russia & RŽD & 1 & 0 & 0 & 0 \\
\hline Belarus & BČ & 1 & 0 & 0 & 0 \\
\hline Belgium & SNCB & 1 & 1 & 0 & 0 \\
\hline Denmark & DSB & 0 & 5 & 0 & 0 \\
\hline & & $\mathbf{1 0 7 7 1}$ & $\mathbf{9 3 8 8}$ & $\mathbf{8 8 7 2}$ & $\mathbf{4 5 4 1}$ \\
\hline
\end{tabular}

According to the data in the Table, the number of passengers, transported by railroads into other states since the year 2002, was gradually decreasing - in 2002, 10771 passengers were transported, in 2003 9388 passengers, in $2004-8872$ passengers and in $2005-4541$ passengers. A decrease of the number of passengers, transported into other states, was mostly effected by the closure of the route Vilnius-Warsaw, as a link to other European countries was broken. This is proved by a decrease of the number of passengers, transported into states, into which passengers were transported through Warsaw; for instance, 1395 passengers were transported to Germany in 2002, in $2005-$ only 99, to Germany correspondingly - 230 and 47 passengers, to Austria - 224 and 59 passengers, to Hungary - 53 and 4 passengers, to Slovakia -65 and 15 passengers, to Italy -78 and 2 passengers, etc.

\section{Analysis of passenger flows on the route Vilnius-Warsaw}

Dynamics of the number of passengers, transported by trains on the route Vilnius-Warsaw and Warsaw-Vilnius during the period of 2001-2005 is covered in Fig 1.
As shown in Fig 1, the number of passengers, transported by trains on the route Vilnius-Warsaw and Warsaw-Vilnius in 2001 and 2002 exceeded the number of 21 thous. - 21555 and 21752 passengers transported, correspondingly. In 2003, this number decreased up to 17235 , and in 2004 decreased even to 16705 passengers, in incomplete five months of 2005 this number amounted to 4136 passengers. A decrease of passenger flows on this route was mostly effected by emergence of low fare airlines in the local transport market, and also by development of transportation by bus.

Passengers from Lithuania to Poland are transported also by other ways - by train from Vilnius to Šeštokai, from there they change to the Polish diesel train "Šeštokai-Warsaw" (also back from Poland to Lithuania).

The number of passengers, transported by trains "Vilnius-Šeštokai" and "Šeštokai-Vilnius" within Lithuania in 2001 made up 83220 passengers, in 2002 it increased up to 97078 passengers, in 2003 flows of passengers remained stable - 97125 passengers, in 2004 flows decreased up to 66168 passengers, and in 2005 they increased up to 83444 passengers.

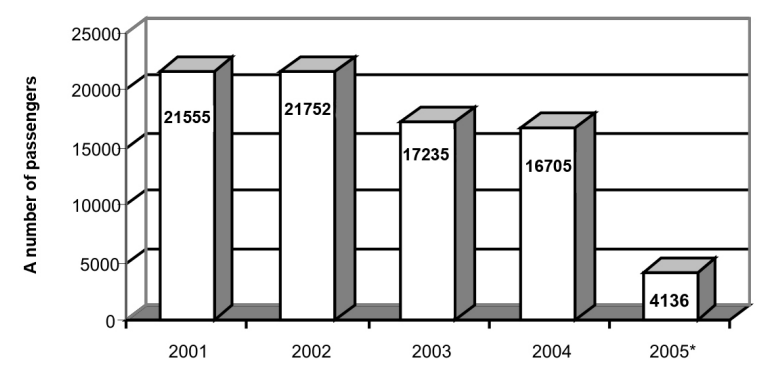

Fig 1. Dynamics of the number of passengers, transported by trains on the route Vilnius-Warsaw and Warsaw-Vilnius during the period of 2001-2005 (* - traffic of trains No 27/28 Vilnius-Warsaw was discontinued, as of 31 May, 2005)

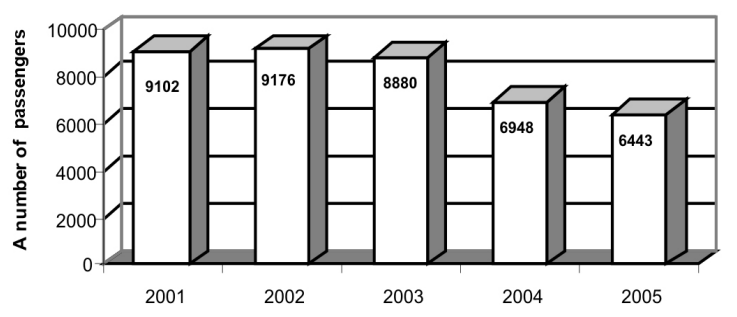

Fig 2. Dynamics of flows of passengers, transported to Poland ant from Poland by trains "Šeštokai-Warsaw" during the period of 2001-2005

As seen in the Fig 2, the number of passengers, transported by trains "Šeštokai-Warsaw" to Poland and from Poland is relatively high in 2001 - 9102 passengers were transported, in $2002-9176$ passengers, in 2003 - 8880 passengers, in $2004-6948$ passengers and in $2005-6443$ passengers.

Thus, the total number of passengers transported from Vilnius to Poland and back, including trains "Vilnius-Warsaw" and "Šeštokai-Warsaw", is high: in 2001 - 30657 passengers were transported, in 2002 - 
30928 passengers, in 2003 - 26115 passengers, in $2004-23653$ and in 2005 - 10579 passengers.

The number of passengers transported to Poland and back by trains "Vilnius-Šeštokai" and "ŠeštokaiWarsaw" in separate months is uneven - the biggest passenger flows are in July - 992 passengers to Poland and 868 passengers from Poland in 2005, correspondingly. Rather high flows of passengers are also recorded in June, July and August - 400, 637 and 432 passengers to Poland and 528, 649 and 475 passengers from Poland, correspondingly. The lowest passenger flows are recorded in January and February.

\section{Research into competitive sphere of passenger transportation on the route Vilnius-Warsaw}

The major competitors of railroad transport on the route Vilnius-Warsaw are road and air transports.

Passengers from Lithuania to Warsaw are carried by Polish state railroads (PKP) (instead of the former train "Vilnius-Warsaw"), by Lithuanian bus companies TOKS, "Autoturas", "Joana", ECOLINES and different tourist agencies.

Based on the author's research, shuttles carry 99108 passengers daily from Vilnius to Warsaw and back.

Traffic of tourist buses from Poland to Vilnius has considerably increased, it is particularly high from May till October. During this period at least one touring bus arrives to Vilnius on working days, 3-4 buses - at weekends and on holidays. Taking into account that one touring bus carries 25-35 passengers, at weekends from 75 up to 140 passengers arrive in Vilnius (on cognitive purposes).

To generalize passenger transportation by buses, it should be noted that in the summer season from 174 passengers on working days up to 248 passengers on weekdays arrive daily from Vilnius to Warsaw and from Warsaw to Vilnius.

Furthermore, some passengers on these routes also go by cars on different purposes - business, tourist and private trips. It is not so simple to define the number of such passengers, however, the analysis shows, that from 15 up to 30 passengers daily go by cars on the mentioned routes.

The total number of passengers, transported by road transport on Vilnius-Warsaw and Warsaw-Vilnius routes, makes up from 189 up to 278 passengers.

Passengers from Vilnius to Warsaw and back are daily transported by the plane "Fokker-50" (50 places) of the airline company "Air Baltic", 20-35 passengers are carried by each flight there and back.

Until 31 August, 2006, passengers from Kaunas International airport were also carried by the airline company "Viz Air", that carried out flights by "Aerobus-320" (189 places) on Mondays, Wednesdays and Fridays. About 80 passengers were carried by one flight, both there and back.

Thus, to generalize passenger transportation by air transport between Lithuania and Warsaw, it was defined that the passenger flow on Mondays, Wednesdays and Fridays made up 10-115 passengers both, there and back, on the rest days - 20-35 passengers, in single direction.

After the "Viz Air" airline company cancelled flights on the route "Karmèlava-Warsaw", there emerged a possibility to take over these passengers for other transport branches - railroad and road transport. Certainly, a part of these passengers was carried by the airline company "Air Baltic".

The ticket price from Vilnius to Warsaw is planned to be $71,3 \mathrm{Lt}$. Similar ticket prices are valid also for buses - from 66,6 Lt up to $97 \mathrm{Lt}$, for plane tickets are much more expensive $-300 \mathrm{Lt}$.

\section{Technical and economical aspects of Lithuanian formation train Vilnius-Warsaw}

Launch of trains, formed in Lithuania and Poland, on the route "Vilnius-Warsaw" and back is considerably relevant for the Lithuanian communication by railroads with the Western European countries.

The train must run daily from Vilnius and daily from Warsaw, i.e. 2 trains, formed by LG and by LKP, should run. The train formed by LG, leaving from Vilnius to Warsaw, should come back from Warsaw the next day, and the train formed by PKP, leaving from Warsaw, would come back from Vilnius also the next day.

The train, running from Vilnius to Warsaw and back, should stop at the following stations: in Kaunas, Marijampolè, Šeštokai, Mockava, Trakiški, Suvalkai, Bialystok, Warsaw (eastern), Warsaw (central) and Warsaw (western).

The train No 27 from Vilnius would depart from Vilnius at 21.44 and would arrive at the western Warsaw station at 5.59 (Polish time), thus, the trip would last for $9 \mathrm{~h} 15 \mathrm{~min}$. The train No 28 would depart from the western Warsaw station at 22.37 (Polish time) and would arrive in Vilnius - at 9.05, thus the trip would last for $9 \mathrm{~h} 28 \mathrm{~min}$.

In the initial stage, till the train formed by LG is not ready, the train formed by PKP should include 2 high-class sleeping-cars (each carriage would contain 10 compartments with 3 sleepers, in total - 30 seats) (WLAB-type carriages) and 2 second-class sleepingcars (each carriage would contain 9 compartments with 6 sleepers, in total - 54 seats) (BC-type carriages).

Thus, train formed by PKP should include 156 seats for passengers and 12 service seats.

According to the plans, in 2007, after the train has been launched in the 4th quarter, 70 passengers would be carried on each passage from Vilnius to Warsaw, and the same number of passengers - from Warsaw to Vilnius; in 2008 - 80 passengers on each passage, in 2009 - 90 passengers. Thus, according to the prognosis, the total passenger flow on the route "Vilnius-Warsaw" in 2007 should make up 64800 passengers, in 2008 57600 passengers and in 2009 - 64800 passengers, a half of which - 6300, 28800 and 32 400, correspondingly - should be carried by the train formed by LG.

The train formed by LG on the route "VilniusWarsaw" should be formed out of the four 
EURONIGHT-type carriages, with 28 seats in each (in total - 112 seats).

The approximate price of one new EURONIGHTtype carriage amounts to 1,2 mill. Euro, i.e. 4,2 mill. Lt, the renovation and modernization cost of one WLAB RIC-type carriage makes up - 0,6 mill. Euros, i.e. 2 mill. Lt [5]. Two train-formation variants are possible:

- Modernization of 4 WLAB RIC carriages and purchase of 2 EURONIGHT-type carriages,

- $\quad$ Purchase of 6 EURONIGHT-type carriages.

In the first case, costs, including also the purchase of 2 heat-engines, would make up 30,4 mill. Lt, in the second case $-39,2$ mill. Lt.

Taking into account the economical comparison of the above said formation versions of the train "VilniusWarsaw", it could be stated that it is not purposeful to modernize the existing four WLAB RIC-type passenger carriages, as they are outdated and do not correspond to the defined requirements. Though WLAB RIC-type carriages with the $1435 \mathrm{~mm}$ track waggons GP-200 are designed for the speed up to $200 \mathrm{~km} / \mathrm{h}$ and with the $1520 \mathrm{~mm}$ track waggons KVZ-CNII-1M - for the speed up to $160 \mathrm{~km} / \mathrm{h}$, following their reconstruction according to the instruction CRB-393 "The technical maintenance of sectors, used by fast passenger trains, structures and facilities", they will be able to run by not higher than $140 \mathrm{~km} / \mathrm{h}$ speed, as they had been produced 12 years ago. The major repairs of carriages and modernization, using the replaceable track axles SUW 2000, would cost about 8 mill. Lt. Formation of a train out of all new carriages would cost 25,2 mill. Lt, but, due to the shorter remained depreciation period of WLAB RIC carriages, their depreciation expenses will be considerably higher than those of new carriages. Furthermore, in accordance with the order of the Communication Minister, as of 16 July 1999, No 282, the major repairs KR-2 of the WLAB RIC-type carriages should be performed in 2014. The major repairs should cost more than 2,0 mill. Lt. Due to the above said reasons, it is more purposeful to acquire new carriages for the train "Vilnius-Warsaw".

These carriages can be produced per 12 months since the signature of the agreement. The total value of the project makes up 39,2 mill. Lt. Furthermore, additional funds should be provided for the acquisition of 8 units of SUW 2000 axles. These axles are required for replacement during the maintenance inspection and during the exploitation in case of defects, as production of one wheel-gauge usually takes 6 months. The price of acquisition of one SUW 2000 amounts to about 115 thous. Lt. The total sum, needed for acquisition of wheel-gauges, would make up 0,92 mill. Lt

Thus, considering the above mentioned economical indicators and the requirements provided under the EU directives for the railroad transport safety and passenger service sectors, it is not purposeful to modernize the old WLAB RIC-type carriages, as they have been used for more than 12 years, are of the old construction and are physically depreciated. To ensure safe passenger transportation and a proper service level, corre- sponding to the EU standards, the LG train "VilniusWarsaw" should be formed out of 6 new EURONIGHT-type carriages. Passengers could be carried by such new carriages and new heating-engines not only to Poland, but also to other EU countries. Thus, there would emerge a possibility on separate routes to compete also with air transport, including the low-fare airlines.

One more significant aspect should be noted - it will be possible to use the EURONIGHT carriages when the "Rail Baltica" route has been completed.

\section{The marketing strategy of launch of the train "Vilnius-Warsaw"}

The publicity campaign "To the Western Europe by train!“", emphasizing the advantages of trips by train against other transport types (cheapness, reliability, safety, regularity, convenience, a sufficient speed, etc.) is recommended.

This campaign should indicate how much cheaper and on what routes, designated to the Western European countries, it is possible to travel by train through Warsaw. Furthermore, it should indicate how long such a trip will last, provide all times of departure-arrival (and changes) and compare the duration of a trip by train with the duration of trips by other transport types.

This marketing campaign should involve mass media: television, radio, press.

The above said campaign "To the Western Europe - by train!" should use the infomercial on trips to the Western European countries through Warsaw, including routes (with changes), advantages of a trip time, price, conveniences, etc.

Moreover, a colored, appealing and informative booklet on possibilities of trips to the Western European countries by train through Warsaw should be published. This booklet should be distributed in railway stations, through travel agencies, in "Vilnius-Warsaw" trains.

To attract flows of passengers to "VilniusWarsaw" trains, cooperation with Lithuanian and Polish tourist agencies should be expanded. Tourists from Poland could be carried from Warsaw by train to Vilnius, here they would be provided with a bus for a trip across Lithuania, later they would be transported by train back to Warsaw. Lithuanian tourists could also travel to Warsaw and back by train and analogous services could be provided for them in Poland. Furthermore, our local tourists could also travel by train through Warsaw to other countries - such as Germany, Austria, Czech, Slovakia, etc. All this could be a result of cooperation with tourist agencies.

\section{Links of the train "Vilnius-Warsaw" with the project "Rail Baltica"}

The completion of the first "Rail Baltica" stage - a section till Marijampole (42 km) - is planned for 20102012. The price of this section makes up about 
400 mill. Lt, including 300 mill. Lt from the EU Cohesion Fund.

The preliminary date of the second stage of "Rail Baltica" - the route from Marijampole to Kaunas is not before 2012 (practically). The price of this section amounts to about 440 mill. Lt.

Modernization of the route "Kaunas-Vilnius" (for a speed of $160 \mathrm{~km} / \mathrm{h}$ ) will cost about 800 mill. Lt.

Based on the author's research, the "Rail Baltica" route should also include St. Petersburg - then cargo and passengers' flows would increase [6].

With the first "Rail Baltica" section equipped, work-teams would change in Marijampolè. In this stage the track replacement equipment should be installed in Marijampole and then the EURONIGHT-type carriages would run up to Kaunas.

With the second "Rail Baltica" section equipped, i.e. from Marijampole up to Kaunas, the work-teams would change in Mockava. In this stage the track replacement equipment should be installed in Kaunas.

In both the first and the second stages the EURONIGHT-type carriages would be used for passengers' transportation up to Vilnius (in the first stage from Marijampole, in the second stage - from Kaunas).

In the first stage Lithuanian locomotives would pull the train up to Marijampole, in the second stage (after the route has been installed up to Kaunas) - up to Mockava.

In prospect, after the next "Rail Baltica" stages have been completed - at first to Riga (in about 2016), then - to Tallinn and maybe - to St. Petersburg, EURONIGHT-type carriages would run on this route (in any stage of the route construction), and 1-2 carriages from the Warsaw train would be disconnected in Kaunas and would run to Vilnius and back, and in Kaunas they would again be connected to the train to Warsaw (see Fig 3).

Thus, to make a conclusion, purchase of the EURONIGHT-type carriages is reasonable, as they would be used in all stages of building the "Rail Baltica" route.

\section{Redistribution of the international passenger transportation market among separate types of transport}

As the author's research showed, with introduction of the fast railway route "Rail Baltica" to Kaunas, the international passenger transportation market will also be redistributed. It has been determined that installation of the above said fast railway route according to the optimistic scenario would redistribute the passenger transportation markets as follows [7]:

- the fast railway would take over from individual cars 15-30 per cent of passengers, travelling to Warsaw, and 40-60 per cent of passengers, travelling to Berlin (5-10 passengers to Warsaw);

- the fast railway would take over from the air transport about 60 per cent of passengers on the route to Warsaw and 20-30 per cent of passengers on routes to Berlin, Hamburg, Amsterdam (20-45 passengers to Warsaw);

- the fast railway would take over from road transport (buses) 40-50 per cent of passengers on the route to Warsaw and 60-80 per cent of passengers on routes to Berlin, Hamburg, Amsterdam, Paris (70-125 passengers to Warsaw);

Thus, introduction of the route "Rail Baltica" to Kaunas would enable railroads to take over about 95180 passengers from other types of transport.

Resumption of the route "Vilnius-Warsaw" will enable to establish the steady passenger flows to Warsaw and to the European countries through Warsaw, and introduction of the "Rail Baltica" route would attract additional passenger flows according to the above stated model.

\section{SWOT analysis}

\section{Strengths:}

- $\quad$ advantages of trips by train - cheapness, reliability, safety, regularity, convenience [8];

- the existing passenger flows among neighbor states and from Lithuania to the Western European countries through Warsaw;

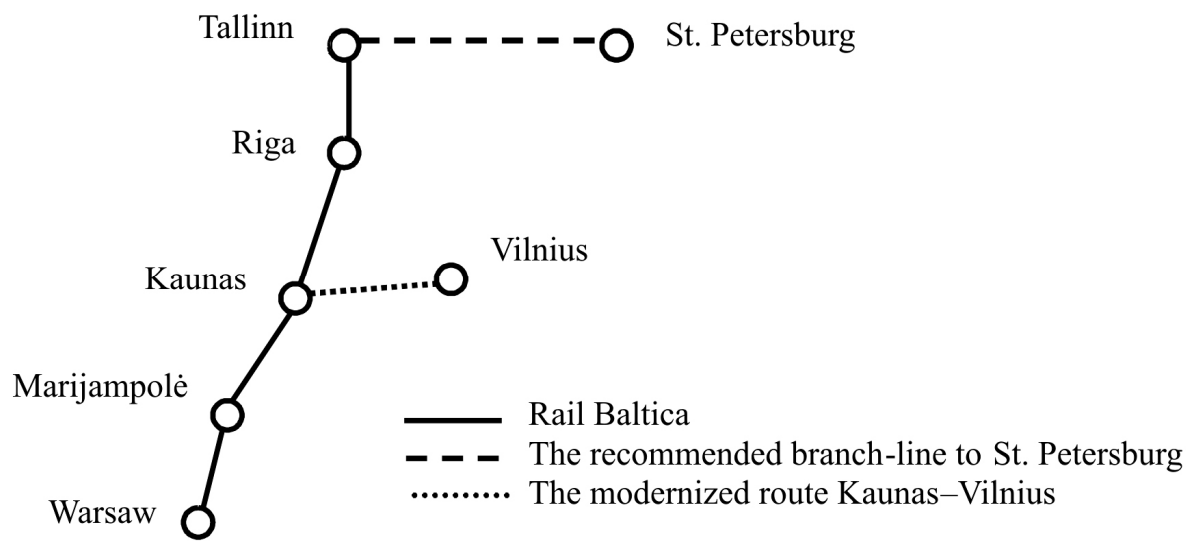

Fig 3. The "Rail Baltica" route with the Vilnius connection and the proposed branch-line to St. Petersburg 
- $\quad$ rather high flows of Polish tourists to Vilnius;

- the communication schedule, convenient for passengers - they can sleep on the train without wasting much time in the daytime;

- $\quad$ not a very long distance of a trip - $575 \mathrm{~km}$;

- introduction of the route "Vilnius-Warsaw" will establish passenger flows for the future "Rail Baltic" line section between Vilnius and Warsaw;

- construction of the "Rail Baltica" line section between Warsaw and Kaunas would considerably reanimate communication by train between Lithuania and Warsaw and through it to the Western European countries;

- the fact that such a route had already existed before and problems of its organization had emerged facilitates the current renewal of the route;

- resumption of the route between Vilnius and Warsaw is supported by the state government;

- a price of trips by train is similar to that of trips by bus, however, it is much lower than the price of trips by planes;

- with acquisition of new EURONIGHT-type carriages and with installation of the "Rail Baltica" line section between Warsaw and Kaunas, these carriages could be also used for other international routes through Warsaw;

- communication by train between Vilnius and Warsaw will be regular (daily), thus, trips to the Western European countries by train through Warsaw will also be regular, whereas planes and buses cannot ensure such a regularity.

\section{Weaknesses:}

- a different width of tracks in Lithuanian and Polish railways causes additional problems;

- acquisition of new carriages for the route or modernization of the old ones and acquisition of locomotives requires additional investments, therefore, in initial stages the route will be loss-making;

- due to closure of the route by train, passenger flows are switched to road and air transport;

- problems with electricity supply for passenger carriages in the sector Mauručiai-Mockava;

- insufficient reliability of operation of the track width replacement equipment SUW2000.

\section{Opportunities:}

- to develop tourist relations with Poland and the Western European countries through Warsaw;

- to attract passengers from other types of transport - road and air transport - due to advantages of trips by train;

- $\quad$ possibilities to use the EU support for development of international communication;

- a possibility to considerably shorten duration of a trip between Vilnius and Warsaw, after the "Rail Baltica" line section from Warsaw to Kaunas is introduced, and at the same time to take over a part of passengers from road and air transport;
- $\quad$ following the effective publicity campaign, a possibility to attract additional passenger flows to the route.

\section{Threats:}

- without the route to Warsaw, Lithuanian inhabitants lose a possibility to go by train not only to Warsaw, but also to the Western European countries;

- without the route to Warsaw, the "Lithuanian Railways" (LG) lose passengers on the main international routes, and later to take them over from other types of transport will be very difficult;

- competition with road transport;

- competition with "cheap flight" airline companies;

- financial assistance to the Lithuanian railroads, related to acquisition of locomotives and carriages, is relevant, as the LG will possibly fail to cover high expenses of introduction of the route by itself (about 67 mill. Lt).

\section{Conclusions}

1. With the entry of Lithuania into the European Union, proper conditions for both Lithuanian and the EU inhabitants to comfortably travel by trains should be created.

2. Lithuania should resume the direct communication by railroads with Poland. For that the passenger train route "Vilnius-Warsaw" should be opened; it would enable the national inhabitants to reach European countries by train and also the inhabitants of those countries to come by train to Lithuania.

3. According to the preliminary calculations, the passenger flows on the train route "Vilnius - Warsaw" in 2007 would be 70 passengers on each trip there and back, in 2008 - 80 passengers and in 2009 - 90 passengers.

4. The train formed by LG, designated to Warsaw, should be formed out of 4 new EURONIGHT-type carriages, each of them including 28 seats (in total -112 ).

5 . In the process of launching a train to Warsaw, one of the major issues is marketing strategy - it is significant to introduce the publicity campaign "To the Western Europe - by train", to considerably develop cooperation with Lithuanian and Polish tourist companies, etc.

6. The author proposes to include St. Petersburg into the "Rail Baltica" route - this would increase flows of both - passengers and cargoes.

7. With introduction of the first "Rail Baltica" line section to Marijampole, the track replacement equipment should be equipped in Marijampolè, work-teams would also change there.

8. With the second "Rail Baltica" stage from Marijampole to Kaunas, work-teams would change in Mockava, and the track replacement mechanism should be equipped in Kaunas.

9. In both the first and the second stages of introduction of the "Rail Baltica" the EURONIGHT-type carriages would be used for passenger transportation to 
Vilnius as well: in the first stage - from Marijampolè, in the second - from Kaunas.

10. In prospect, with introduction of the next stages of "Rail Baltica" - at first to Riga (in about 2016), later to Tallinn and possibly - to St. Petersburg, the EURONIGHT-type carriages would run on this route in any of its introduction stage, and 1-2 carriages from the Warsaw train would be disconnected in Kaunas and would run to Vilnius and back.

11. Resumption of the train route "VilniusWarsaw" would enable to establish steady passenger flows to Warsaw and to the European countries through it, and introduction of the "Rail Baltica" route would attract additional passenger flows in accordance with the model provided under the article.

\section{References}

1. White book. European transport policy for 2010. Europe Commissions. Brussels, 2001.

2. BAUBLYS, A.; BUTKEVIČIUS, J. The development of freight and passenger transportation by railway across the Lithuanian/Polish border. In Humanisation of Technology. Vilnius: Technika, 2001, p. 31-35.

3. KOPPEL, O. Rail transit policy of the European Union and Estonia: objectives and outcome. Transport, 2006, Vol XXI, No 3, p. 1a-1g.

4. ŠAKALYS, A.; PALŠAITIS, R. Development of intermodal transport in new European Union states. Transport, 2006, Vol XXI, No 2, p. 148-153.

5. BUTKEVIČIUS, J.; LINGAITIS, L. P.; VAIČIŪNAS, G. The strategy of resumption of passenger equipment part of Lithuanian railway. In Transport means. Proceedings of the International Conference. October 28-29 2004, Kaunas: Technologija, 2004, p. 107-111.

6. BUTKEVIČIUS, J. The passenger transportation (Keleivių vežimai). Vilnius: Technika, 2002, p. 272-275 (in Lithuanian).

7. BUTKEVIČIUS, J. The research into development of passenger transport by land. Transport, 2004, Vol XIX, No 5, p. 195-201.

8. KNUTTON, M. Time for a re-think of high-speed rail priorities. International Railway Journal, 1999, No 7, p. 14-17. 